\title{
CONSUMING CHILDREN AND MAKING MOTHERS: BIRTHDAY PARTIES, GIFTS AND THE PURSUIT OF SAMENESS
}

\author{
Alison J. Clarke \\ University of Applied Arts - Austria
}

\begin{abstract}
Children's birthday parties, and related consumption, form an integral part of the social process of mothering in contemporary consumer culture. From the choosing of the 'right' present to the arrangement of the 'appropriate' party theme, an enormous pressure is exerted upon mothers to maintain social equilibrium through the circulation of their children and gifts amongst and across households. Ethnographic research in Britain suggests that the economic growth of children's party provision and services is coupled with a popular discourse that laments the loss of 'authentic' kinship-based birthday parties and home-made provisioning. In contrast to this spoken discourse, this article reveals how women in fact avidly embrace market goods and services; as a means of generating a culture of sameness that avoids the risks (to the motherhood as a collective, localised phenomenon) of exceptional or overtly accomplished mothering. Commercialised, mass produced goods and birthday services are used as a means of limiting expressive gift relations and hospitality. In this sense, the search for sameness, through the cultural practice of making children's parties, is at once liberating and potentially oppressive in its strive for the normative and its inadvertent exclusion of 'other' care-givers. Furthermore, children and their related material culture are consumed, through the birthday party circuit, as a means of generating specific types of mothering.
\end{abstract}

Keywords: children's birthday parties, contemporary motherhood, gifts, material culture.

Resumo: Festas de aniversário infantil, e o consumo ligado a elas, formam uma parte integral do processo social da criação dos filhos na cultura de consumo contemporânea. Da escolha do presente "certo" à preparação do tema "apropriado" para a festa, uma grande pressão é exercida sobre as mães para manter um equilíbrio através da circulação de suas crianças e seus presentes entre e além das famílias. Uma pesquisa etnográfica na Grã-Bretanha sugere que o crescimento econômico dos preparativos e serviços para festas infantis está ligado a um discurso popular que lamenta a perda da festa de aniversário "autêntica”, baseada na relação familiar e nos preparativos feitos em casa. Em contraste a este discurso falado, este artigo

Horizontes Antropológicos, Porto Alegre, ano 13, n. 28, p. 263-287, jul./dez. 2007 
revela como as mulheres, na verdade, adotam com avidez produtos e serviços do mercado, como uma forma de gerar uma cultura da mesmice que evita os riscos (à maternidade, como um fenômeno coletivo e localizado) de uma criação dos filhos incomum ou declaradamente realizada. Os produtos e serviços para aniversários comercializados e produzidos em massa são usados como um meio de limitar as relações expressivas de presentes e hospitalidade. Neste sentido, a busca pela mesmice, através da prática cultural de fazer festas infantis, é ao mesmo tempo libertadora e potencialmente opressiva em seu esforço pela exclusão normativa e inadvertida de "outros" cuidadores. Além disso, as crianças, e a cultura material relacionada a elas, são consumidas através do circuito de festas de aniversário, como um meio de gerar tipos específicos de criação dos filhos.

Palavras-chave: cultura material, maternidade contemporânea, festas de aniversários de crianças, presentes

It was Barbie last year for my girl, Batman for the boy - with all the trimmings it came to over $£ 300$ a party; and that was working to a budget. (Miranda, 34, mother).

Tessa [ten year old daughter] was invited to a friend's birthday party in the summer at a top London restaurant. The kids were all driven by chauffeured limousine, had a four-course meal and then went on to a West End [theatre] production. I mean, that's ridiculous what can a ten year old expect next? (Gillian, 36 , mother).

Over the last decade the children's birthday party has emerged as a key arena of mass consumption that generates an enormous range of specialised commercial merchandising, services and products ranging from Disney themed disposable tableware to mini-marquees for the garden. As a mode of cultural activity that spans the intimacy of familial relations and established traditions of commemoration, consumption and aesthetic discourse around birthday parties offers a unique insight into the contradictory nature of contemporary parenting. ${ }^{1}$

\footnotetext{
Parenting refers here to the process of nurturing and raising children. The article uses the term 'parent' to refer to any individual (relative, carer, etc,) given the principal duty of overseeing the child's day-to-day care. This particularly article refers ostensibly to women (mothers) as the key parenting figures as evidenced over the course of the ethnography.
}

Horizontes Antropológicos, Porto Alegre, ano 13, n. 28, p. 263-287, jul./dez. 2007 
The typical contemporary child's home-birthday party commonly involves the careful selection of a theme (Barbie, Harry Potter, pirates, wizards and dragons, fairies and queens etc); the making or buying of the ideal cake; the choice of miniature items for guests' 'gift-bags'; the co-ordination of ageappropriate games and activities; the purchasing or making of party clothes or fancy dress outfits; the selection of party plates, cups, hats and tablecloths; the making or shopping for desirable party treats and snacks and, most importantly, the careful selection of just the right number and range of party guests. These selections are weighed heavily against the myriad of choices exercised by other parents at previous parties and the potential choices of future parties. Hence the children's birthday party occupies, besides its obvious role as a marker of age, a heightened temporality as a genre of consumption.

As British children's parties have evolved as more elaborate affairs, they have also become increasingly commercialised. Enterprises such as, McDonalds fast-food outlets, Kid Zone play activity areas and Party Pieces catalogue (selling ephemeral wares exclusively for children's parties) are widely incorporated into children's party planning across Britain. Smaller scale enterprises, such as one-off 'bouncy castle' rentals, and the 'Paint Your Own Pottery' party shops that have emerged in streets corners with child-centred demographics, are testament to the enormous economic and social significance of the birthday party. Given the enormous amount of labour and social anxiety generated by the typical infant's birthday party in recent years, it is perhaps not surprising that such parties have become increasingly commercialised, incorporating the paid services or venues of external companies or 'specialists' as a means of assuaging the enormous organisational pressure. As cultural geographers, sociologists and cultural economists (McKendrick; Bradford; Fielder, 2000; Otnes; Nelson; McGrath, 1995; Zelizer, 2002) have identified, the children's birthday, either commercial or home-based, is a social and consumption ritual that is gaining, rather than waning, in significance in contemporary consumer society. $^{2}$

Does the burgeoning culture of children's parties signal the vibrancy of neighbourly relations and friendships? Or is this commercialisation of an idealised

\footnotetext{
For research regarding the institutionalised aspects of children's parties see Handelman and Handelman (1991).
}

Horizontes Antropológicos, Porto Alegre, ano 13, n. 28, p. 263-287, jul./dez. 2007 
facet of domestic work, the preparing for and shepherding of a child through the symbolically pertinent social ritual of the birthday, yet more evidence of the penetration of market forces into the sacrosanct non-economic worlds of children and motherly love?

Using excerpts from a broader ethnography of household consumption in north London, ${ }^{3}$ this chapter explores the intersection of commerce and mothering and argues that birthday parties are rarely organised as singular expressions of parental/child relations but rather as part of a broader gendered sociality in which networks of gifts and children are circulated in rounds of reciprocity. The increasingly aestheticized and elaborated nature of children's parties and their intertwining of material culture, social relations and commerce is a form of consumption that is not merely an extension of women's domestic work, but is rather a testament to the ways in which mothering and consumption have become a mutually constitutive phenomenon (see Clarke, 2004). It might be convenient to represent the careful preparation of the party event, and the sophisticated gift-giving culture negotiated between mother and child in the attendance of rounds of reciprocal birthday parties, as being redolent of a social anthropologist's classic model of 'authentic' feminised non-market sociality. On the contrary, however, this article suggests that it is through (rather than despite) the appropriation of the market, in the form of mass-produced food, decorations and material culture, commercially hired venues that women as mothers attempt to subvert the tyranny of idealised roles as carers and negotiate alternative renditions of being a 'mother'. It also considers how mothers situate themselves in social class terms through their children and related ethics around consumption as seen the spectacle of the birthday party.

3 The ethnography involved 76 households in total and included a range of ethnic and social backgrounds representative of a fairly typical London semi-urban street including white British, Southern Irish, Greek Cypriot, Chinese, Jamaican, Colombian, West African, Pakistani, Jewish South African, etc. The field site research was initially established in 1994/5 but has been used for subsequent research in 2004/5 on which this article is based. This particular article incorporates research obtained though a combination of techniques including object biographies, taped interviews and full participant observation in events ranging from shopping trips, birthday parties, schools fairs, jumble sales, Tupperware Parties and other daily domestic routines. For a more detailed discussion of the field site in relation to child-rearing see Alison J. Clarke (2004) and Alison J. Clarke (2000). 


\section{Potlatch and Lucky Bags: Making the Perfect Party}

On Jay Road, an ordinary street in North London, ${ }^{4}$ Julie, the mother of a six-year-old girl, laments that a mother 'unfortunate' enough to have their child's birthday fall in August (between school in-take years) might have attended over twenty parties since the previous September due to the number of friends her child has accumulated. The sheer financial and organisational labour led many mothers to be increasingly ambivalent about "the snowball effect" of arranging and attending party after party, and buying a seemingly endless round of suitable birthday presents.

Belinda, a mother of three children living in a street adjacent to Jay Road, observes that the 'party circuit' seems to have expanded in size, and lavishness since she was a child brought up in the same neighbourhood. Her own children expect birthday parties at commercial venues (such as a paint-gun play centre or water-world theme park) at enormous cost, and Belinda wonders whether this signals a shift in her own class mobility or a general boom due to increased consumerism and the increasing 'pester power' of children;

It's just a different world to the one I was brought up in. I think they just make life so difficult for people these days - all this... we never had birthday parties when I was younger we had family birthday parties - we had a few cousins come over and that was it - and it was much easier and it was much less harassment for my mother. I think it's a bit of 'keeping up with the Joneses'.

Although, in the past, Belinda keenly organised extravagant children's parties at home and expensive 'themed' activity-events in commercial venues,

4 The street, the site of the ethnography conducted between 1996-1999 (with follow-up study 2003) as part of a broader ESRC funded project into consumption (see Miller, 1998; Miller et al. 1998) consists of mixed housing (state and private owned/rented). Equidistant from a leafy suburban area and a busy inner city area, the street was described by some informants as being 'semi-suburban' and an ideal compromise for rising children in London. The informants forming the empirical basis of this article are predominantly white British or Southern Irish; this is due to the very nature of the article's main thesis. That localised modes of mothering are made, through the circulation of goods, tastes and infants, to the exclusion of other groups and manifestations of mothering. Through ethnographic detail this article highlights how certain informal social solidarities come to dominate particular localities.

Horizontes Antropológicos, Porto Alegre, ano 13, n. 28, p. 263-287, jul./dez. 2007 
she describes more recent attempts to 'opt-out' of an 'escalating party scene' by introducing a price-cap on her ten-year old son Jake's parties and suggesting simpler options - like a football match with friends in the local park followed by burgers and chips at home.

While Julie and Belinda try to find ways to negotiate the sheer enormity of the commitment to children's parties with 'down-sizing' strategies, round the corner Camilla Knowles, mother of four young children, day-dreams about themes and novelties for her children's parties. In the summer her three-year-old daughter, Caitlin, had a 'gypsy' party and Camilla made a cake in the shape of a Romany caravan surrounded by fresh flowers (as described in the opening quotation). She made 'lucky-bags' (party gifts bags) from hand-painted muslin filled with 'lucky charm' sweets and novelties that she had collected on numerous shopping trips for the fifteen child-guests to take away at the end of the party, along with a slice of birthday cake in monogrammed cake tins. Camilla is particularly proud of the unique party-bag gifts, small raffia donkeys and horses, which she bought whilst on holiday in a remote Italian village, as there is absolutely no equivalent in the local shops and they cost only 50 pence each.

Camilla is well known amongst mothers in and around Jay Road as she attends many National Childbirth Trust (NCT) ${ }^{5}$ mothers' meetings and events and is dubbed ' super-mum' by her peers due to her unflappable ability to deal with four excitable young children and run a 'homely' household. Her home, a terraced Victorian house on one of the leafy streets adjacent to Jay Road, is given over entirely to the children who are allowed to play unhindered in all areas of the house. Camilla is a fulltime mother and the family live on the husband Jeremy's income as a trainee barrister. The 'romantic' chaos of the Knowles' home is often evoked by other mothers, familiar with Camilla and her style of liberal and creative mothering, as an idyllic scene of domesticity. Mothers on Jay Road marvel at Camilla's birthday parties and view them as the pinnacle of a mode of creative mothering in which attention to detail is manifest, not in scraping old, dried baby food from a high-chair, but in icing roses on a birthday cake.

\footnotetext{
${ }^{5}$ The National Childbirth Trust was previously named the 'Natural' Childbirth Trust as it originated as a pressure group and charitable organisation promoting breast-feeding, non-medical intervention and 'drug-free' birth. Although it has more recently aimed to popularise its appeal, its meetings and branch organisations are still ostensibly representative of liberal middle class parenting. For specific reference to the local manifestations of this organisation see Miller (2004, p. 33-34).
}

Horizontes Antropológicos, Porto Alegre, ano 13, n. 28, p. 263-287, jul./dez. 2007 
Jenny, a middle-class mother living in the leafy side of the London suburb, is typical in her aspiration to provide an original party theme that will please both her seven-year old daughter and the unspoken aesthetic rules of the mothers of her daughter's friends. The party should incorporate some 'home-made' elements as a measure of commitment and housewifely skill; but it should not exceed a certain measure of domestic creativity in the event that it might look too forced or 'keen'. Jenny was particularly sensitive to what she described as 'the balancing act' involved in making a good party as she had recently attended an event with her seven-year old that left her feeling wholly 'inadequate';

There it was, in the middle of a table strewn with fresh rose petals; a home-made birthday cake in the shape of a Romany caravan. I mean, I'm not joking! It had coloured icing curtains and chocolate Flake wheels. The gift bags, napkins and plates and everything ... everything was co-ordinated with the 'folky-Gypsy' theme. ....all for a bunch of three year olds who'd rather have been stuffing their faces at McDonalds anyway!

The overt anti-commercialism of Camilla's party, as described from the perspective of a local mother, is the highest form of ostentation and a betrayal of normative notions of contemporary motherhood generated amongst the socialising middle-class mothers in locality. While 'natural' home-made goods (like non-medicalised birth) might be the acknowledged ideal, to acquiesce to the pressures of modern motherhood through the purchase of 'short-cut' convenient products of commercialism (such as packet cooking dough, plastic gifts, etc) is the unspoken but widely recognised and admired reality. The dialectic relation of the consumptive ideal (as expressed in Camilla's party) and the consumptive reality (as exemplified by McDonald's corporate parties), and its constant negotiation, sustains the communality of local mothers. ${ }^{6}$

Of course, much of the idealisation of Camilla's birthday parties is a type of exaggerated consensual projection generated by other mothers, rather than a social reality. For they construct Camilla's efforts in opposition to their collectively experienced 'failure' in managing the perfect reciprocal event as a

6 For a comparable exploration of the process by which mothers 'grow' by 'giving-in' to the contamination of commercialisation in the form of their infants' acquisition of Barbie dolls see Miller (2004).

Horizontes Antropológicos, Porto Alegre, ano 13, n. 28, p. 263-287, jul./dez. 2007 
means of re-instating the acceptability of incorporating consumer goods and services into their mothering. It is in the form of chat and gossip, at coffee mornings and at other children's birthday parties, that such opinions are generated. And mothers in Camilla's social circle openly confide their dread at having Camilla's children attend their parties in case they are showed up by trotting back home with 'embarrassing, tacky gift-bags' the contents of which had not been sourced in a rustic Italian village but rather Woolworths cheap department store on the local high street.

Children's birthday parties, their organisation, design and orchestration could simplistically be viewed as the epitome of the 'invisible labour' of the gendered work of caring (Devault, 1991); for, as highly valorised spectacles, parties reveal the otherwise unseen consumptive and aesthetic skills of everyday nurturance. But the social pressure, escalating expense and public display of contemporary children's parties is perhaps most easily analogous to that of the anthropological 'potlatch' famously described by (Mauss, 1954) as a prestation totale whereby the exchange involved the total social personalities of the exchangers (Davis, 1992, p. 7). The 'potlatch', a highly symbolic event of conspicuous consumption, in which those that have received goods and gifts strive to give more in order to preserve and increase their social power and standing, was understood by Mauss as the anti-thesis of the rational exchange which typified industrialised societies. Certainly, there can be no 'rational' explanation for the expenditure (in terms of time and money) incurred by households in the organising and funding of children's parties, the expense of which most often contrasted sharply with the budgetary constraints of householders on the street. But neither is this merely a model of economic instrumentalism, whereby household resources are implemented in the acquiring of social status and the expansion of its social resources (Anderson; Bechhofer; Gershuny, 1994; Wallman, 1984). Why, then, do women (as mothers) feel compelled to invest in this seemingly stressful, emotionally exhausting and resource-sapping round of socially pressured parties they view with such ambivalence?

In an extensive, North American based study of children's birthday parties, sociologists Otnes, Nelson and McGrath (1995) argue that the event is principally used by mothers in the socialisation of their children through the use of 'ritual artefacts, scripts, performance roles and the ritual audience to teach children both general knowledge and values, and specific behaviours necessary for the successful participation in this ritual' (Otnes; Nelson; McGrath, 1995, p. 622). 
Many of the acts of socialization identified in the Otnes et al. study revolve around the steering of infants away from unacceptable commercial party themes to less offensive versions. At the time of their research, Ninja Turtles (fighting cartoon characters) held much currency on popular children's TV and several of the mothers spent much time persuading their sons to opt for a 'less aggressive' party theme. Numerous mothers in the study also expressed anxiety over allowing competitive games at their parties and tried to engage the children in democratic activities in which 'everyone wins'.

Gift-giving similarly provoked anxiety in the mothers in Otnes' et al's study. Whilst the excited unwrapping of gifts formed the focus of the party, mothers keenly sought to avoid expressions of wanton materialism by promoting their child's 'graciousness' in receiving presents (particularly unwanted gifts). The giving of 'lucky bags' at the end of the party was a means, like the preference for non-competitive games, of ensuring all children experienced recognition and reward.

The authors, then, consider every facet of the child's birthday party, from its planning through to the flavour of its cake and the unwrapping of gifts, as a series of opportunities for the mother's direct socialisation of the child. The acute attention to detail and the anxiety invoked by the children's parties is accounted for solely in the mothers' driving (and apparently innate) desire to appropriately educate their child in the appropriate manners and mores of contemporary social ritual. ${ }^{7}$

The mothers from the Otnes et al. study are middle class, fully employed and the majority are Caucasian and married with two children. As they are taken from the same work based day-care centre (a state University in the Mid-West) they most likely also share some broader values or at the very least encounter each other in child-related social situations. In other words, these women belong to some rendering of localised mothering. What, then, if we were to invert the emphasis of the Otnes study and instead suggest that the objects of anxiety where not in fact the children, but rather were the mothers themselves? The birthday party is an opportunity to publicly display notions of 'good' or 'appropriate' mothering, and the appeal to children to show graciousness

For comparable study of relation between parental edification in North America and social class differences see Annette Lareau (2000).

Horizontes Antropológicos, Porto Alegre, ano 13, n. 28, p. 263-287, jul./dez. 2007 
in opening presents, and restraint in eating chocolate cake is as much directed towards the 'other mothers' as it is to the child itself.

For Harriet Smith, on Jay Road in North London, birthday parties are an enormous source of anxiety. As a comparatively shy person herself, Harriet is eager to encourage her three-year old daughter, Sara, to develop social confidence. Like Camilla, Harriet attends NCT 'get-togethers' but her approach to childcare and household organisation differs greatly from the liberal chaos of the Knowles' home. Harriet, who has just one child, keeps an immaculate home with pristine décor and toys fastidiously stored away in labelled boxes in an under-stair toy cupboard.

A recent incident in which Sara refused to share her toys with a child of a visiting mother, led Harriet to feel embarrassed, ashamed and annoyed by her daughter's behaviour which had 'shown her up'. Although Harriet and her husband Bob live in a larger than average Victorian house in a road adjacent to Jay Road, the family depends on Bob's fluctuating wage as an electrician and consequently the couple budget conscientiously. Except for the local NCT gatherings, Harriet is socially isolated and has only recently started attending the round of children's birthday parties in the neighbourhood. This has meant the acquisition an entirely new set of outfits for Sara; 'We've had a lot of birthday teas lately so I've noticed a lot of the girls wear dresses to that. But usually it's leggings and jumpers, dungarees things like that, but I put her in a dress for the parties.'

At first glance, this ethnographic excerpt appears to substantiate the idea of children's parties as a key arena of socialisation, used didactically by mothers whose sole concern is the social betterment of their offspring. But Harriet's desire for her daughter to 'behave properly' and wear the right clothes at birthday teas (dresses as opposed to everyday androgynous clothing) is inextricably bound to her desire to 'fit-in' to the local modes of mothering. Harriet is exceptional in the level of her insecurity and self-consciousness regarding 'doing the right thing', but she is by no means exceptional in her tendency towards perpetual comparison and a heightened consciousness of 'other' mothers.

Penny, mother of a three-year-old daughter living on Jay Road, recalls one incident, in which the addition of Smarties [branded multi-coloured chocolate sweets] to a party caused much consternation amongst the mothers:

We never give sweets, I mean sweets would be probably a kind of class thing but basically sweets are never on offer at an our mothers' meetings...In our group 
there is quite a good sense of tolerance for other people's, you know, there was that kind of incident a couple of weeks ago we went to the first [in a round of] 3rd birthday part[ies] ... it was done by one of the mothers who is, who probably has the same attitude as me; "they love Smarties, it's a party, [so] give them Smarties". I was sitting next to my friend whose child has not had sweets and [she] said, "this is the end of my beautiful pure-bred". I said, "Yes it is, it is. You have to accept she's going to come to these birthdays". And so we were laughing at the whole thing, and she agreed that that was the end really. And I said, "look you've given her a good start. She'll just have to learn that there are limitations”.

As revealed in the interaction above, it is through such events and exchanges that consensus is made through the process of mothering; in this case in reaching accord over the cultural acceptability of branded sweets. The woman responsible for organising the first in a round of birthday parties for three-year peers, clearly broke a sacred, but unwritten, rule regarding the exposure of infants to impurities such as sugar. The act of offering inappropriate food-stuffs to infants within the group might have been deemed wholly unacceptable; thus placing the initiating mother in an uncomfortable position (exposing, as she is, the disjuncture of her values to those of the broader group of mothers). However, the transcendent nature of the event (children's birthday party) is deemed by at least one mother (who then goes on to persuade another mother) as a perfect justification for the challenging or breaking of previously established values within the group. In this way consensus is generated and negotiated amongst the women over 'mothering' through the provisioning of parties and the continued circulation of infants and children. Although the pretext of the parties is the children themselves, it is the mothers and their discourse of mothering that predominates the proceedings; but it is not merely a discourse of how to be a better mother. On the contrary, interactions tentatively generate around the everyday ambivalences of being a mother (Parker, 2005); from how much time one should have to oneself ("is TV okay as a baby sitter for just a few minutes?") to what is an acceptable level of engagement with the infant ("do you actually get on the ground and play with your child - I'm too busy?”). But these ambivalences tend to arise, not in the form of these direct conversational excerpts but rather through the common currency of commercial goods and the confluence of taste and mothering style as witnessed in the giving of birthday party gifts; should baby boys wear branded sportswear or romper suits; are plastic toys good or bad? 


\section{'Other Mothers': Making a Sociality of Sameness}

In their ethnographic study of the social contacts of women with preschool children in South East England, Bell and Ribbens (1994) challenged the simple conflation of the terms 'isolated' and 'housewife' that typified sociological descriptions of mothers in industrial societies. While it is crucial to consider the change in women's domestic lives in the context of their work as child-rearers, they argued that the pre-occupation with the isolation of domesticity undermines the "importance of [the] apparently insignificant or invisible networks" of women's lives (Bell; Ribbens, 1994, p. 227). The ambiguity of women's roles as mothers poses (as either source of oppression or source of power) within feminist discourse is well documented (Devault, 1991; Everingham, 1994; Parker, 2005; Segalen, 1986; Stacey, 1986) as is its ambiguity within the context divisions of 'formal' and 'domestic' economic activity (Ferber; Nelson, 1993; Pahl., 1984, Redclift; Migione, 1985). For this reason, Bell and Ribbens suggest, social research has largely ignored, or at best under-estimated, the significance of women's social contacts as mothers.

Isolation, then, is certainly not the automatic result of motherhood in an urban setting. But the extent to which mother-to-mother relations offer emotional fulfilment to women raises further questions, as women's friendships have largely been assumed in social science as an extension of their roles as mother or wife rather than as a serious object of study within themselves (Allan, 1996). Women's ability to establish social networks undisputedly relies upon access to broader resources that differ enormously according to locality, ethnicity and social class (Tivers, 1985; Wallman, 1984; Werbner 1988). Furthermore, the pursuit of sociality or 'community' should not automatically be considered as beneficial or sought after by mothers in preference to a perceived 'isolation' as women have frequently sought to affirm or undermine certain social class and ethnic identities through actively distancing themselves from specific forms of female sociality (McCannell, 1988; Sharma, 1986). But what is clear from the ethnographic insight offered by this study of children's birthday parties, is that becoming a mother is as much a social and cultural as a biological process (Layne, 1999) whereby commercial culture (in the form of gift-objects, clothing, services, foods etc.) is paramount in transforming everyday domesticity into the generation of specific types of meanings and social solidarities within mothering.

As highlighted by Bell and Ribbens (1994) it is during the early infancy of their children that mothers are most likely to seek solidarity with other mothers 
and in this sense the role of children's birthday parties evolves as children grow up. Sally, the mother of eight and ten year old sons, living in a maisonette on Jay Road, used to enjoy birthday parties when her children were toddlers as it was an 'excuse' to get together with other mothers and have a glass of wine and 'a laugh'. Now she dreads the time of year around which her children's birthdays fall; 'I used to enjoy spring but now, oh no! It's such a pressure because it's both of the boys' birthdays!'.

In early infancy the child is almost entirely a construct of its mother but as this gives way to the increasing agency of the child, who demands everything from the style of their party outfit to the types of presents, the mother's ability to supervise and oversee the outcome of the social event becomes more limited. But also the woman's role as mother and her own identity and standing within these terms, is less likely to need negotiation or reiteration as at the early stages of child-rearing. For some women the prospect of hosting birthday parties for their older children is filled with even more anxiety; enjoyable only for those mothers with the least to risk, and the most to display, as expressed by Joanna;

Well - I don't know. I sound as if I'm being a bit 'classist' here, but I wonder if it's [children's party culture] more of a middle class thing. That is to say, what I was used to when I was a younger - we were much more...I don't know whether it's access to money - having less money than we've got now but I can't remember being invited to birthday parties. So either I was a very unfriendly or unliked child or we just didn't do it. Some people seem to thrive on it as well - like my cousin's 'set', they seem to go to millions of parties and she looks on it, sort of all, very generously and thinks it's all great. And I just find throwing them traumatic. I'd do anything rather than give a party I just don’t like it.

The enormous pressure of children's parties, the increasing materialism and commercialisation identified by numerous informants, reveals an entirely contradictory relation between discourse and practice. On the one hand, like Joanna, mothers spoke nostalgically of the small scale, kin-based parties they experienced themselves as children and lamented the rise in commercial intervention. Yet on the other hand, the very same mothers regularly incorporated party services and mass-produced goods into their party provisioning.

A typical commercial enterprise aimed precisely at mothers like Joanna is Party Pieces; a catalogue and on-line service dedicated to the accessorization of children's parties, offering goods such as fancy dress outfits, decorated paper cups, party games and prizes, banners and balloons. Mothers receiving the 
catalogue complete a form listing the dates of their children's birthdays and receive the catalogue in the post two months prior to the date of a specific child's birthday. As well as providing ideas for themed parties the catalogue appealed to mothers such as Philipa (despite awareness of paying over the odds for the merchandise) as an expedient way of shopping while creating innovative parties;

I've bought things from the Party Pieces catalogue but you can try be a little bit less extravagant really - I probably wouldn't tend to depend completely on it- I don't think they are that pricey but the whole thing always adds up in the end you end up buying more, rather than if you had just gone out and bought a few white plain paper plates - if you get the whole thing co-ordinated and masks and that sort of stuff.

The expansion of formal businesses into the previously 'home-made' arena of 'dressing-up' and 'fancy dress' costumes and accessories seems further testament to some mothers of the commercialisation of children's worlds. As well as catalogues featuring festive wares, more recently a local woman in the neighbourhood had been organising 'children's fancy dress direct-sales parties', showing a range of costumes from Dracula to Fairy Queens. Gathering together in the house of a volunteer hostess, mothers sip wine and handle a range of children's fancy and dressing-up wear and choose from a stand-up cardboard model showing prices descriptions and costume types. In general, the costumes were considered overly simple in relation to the prices charged for them. A pirate costume, for example, consists of a black patch and a pair of shorts resembling pyjama bottoms; an ensemble several mothers considered insultingly easy to have put together themselves.

However, Sally, despite being aware that the items must have been made with a large profit margin in mind, bought a 'beautifully made satin cloak' to dress her daughter as a vampire as she admitted she would never have 'got around' to making such an article herself. Other items, fairy dresses and ballet costumes merely consisting of a piece of white nylon netting hanging on a piece of elastic, were seen as unacceptable in terms of their value for money and "too embarrassing" to purchase.

For some mothers the overt commodification of the catalogue undermines the entire project of the children's party and takes away the creativity of inventing games, costumes, decorations and prizes. Jane, for example, enjoys making 
homemade items, to create a co-ordinated theme. She used the closeness of Halloween to her daughter Rachel's birthday as a theme for her fifth birthday party, organised in conjunction with another mother, in the local church hall. As it was a fancy dress event, Jane had spent several evenings sewing a witch's outfit for her daughter from scraps of fabric from a local remnant store. She made jamboree bags filled with 'bits and bobs' from Woolworth's and had cut out paper decorations to string across the walls of the hall. Both mothers spent evenings carving out pumpkin lanterns and hand-made invitations with pop-up ghosts had been sent to around twenty children. A birthday cake in the shape of a 'scary monster' with the names of the two girls iced on top formed the centrepiece of the food. Working to a limited budget, Jane viewed the creative aspect of the party-making as crucial element of its value and she encouraged Rachel and her small brother to make invitations and decorations at the kitchen table with her.

The night before the event Rachel insisted on abandoning her proposed witch's costume insisting instead on dressing as a 'good fairy'. As well as preparing the party food of pizza, cheese sticks, jelly and fruit, Jane set about constructing a fairy costume from white netting and tinsel, to pacify her distraught daughter;

I couldn't believe it! All that effort and then she goes and wants to be a fairy - it totally ruined the whole theme... and she looked like a very ragged fairy. I felt like selling the witch outfit I'd made to another mother for a Halloween party!

The disappointment expressed by Jane in undermining her fully orchestrated event is not unusual. Despite the pressure, sheer labour and anxiety involved in dressing, transporting and equipping children for their attendance of birthday parties it is most often the children, rather than parents, who resist attending the events. On several occasions in the course of the ethnography there were heated 'scenes' between mothers and children when, often a short time before the commencement of a party, a child had firmly refused to leave their home or get out of the car at the venue. As Jenny comments in the case of smaller events, or those organised around a paid commercial venture, in which a child's absence will be noticed mothers feel a sense of obligation and pending disgrace; 'Sophie had been invited to one [birthday party] this weekend but she wouldn't go - and there was no contact number and I haven't seen that mum since so... I must apologise.’ 
As well as the resources required for the organisation of children's birthday parties a number of strategies are employed to deal with the sheer volume of gifts required in the attendance of the yearly 'rounds' of parties. Jenny, for example, uses a two-tier approach to birthday gifts for her children's friends (as also described in Sirota's (1998) study of children's birthday gift-giving in Paris). For general school friends' parties she uses a collection of Woolworth's items, amassed throughout the year in the course of everyday household shopping trips. For closer friends' and best friends' birthday parties she uses the Early Learning Centre catalogue and specific shopping trips to make selections. She also keeps a bulk of children's birthday cards in a drawer of the living room cupboard and uses the corner shop 'in emergencies' if she runs out of appropriate cards. For members of her own family Jenny uses trips abroad, for example, to try to find items a little more special. Although family gifts can be postponed, delivered at a later date, gifts for the children's of other mothers are a more pressing concern and onerous task;

Most of the presents I buy are for the children to take to parties ...I owe my other cousin's little boy a present - he was four so I've got to get him something - I've got a huge family so it costs me a fortune in presents and also the kids have acres and acres and friends which is good, you want them to have friends, but sometimes the parties and the buying gifts can be a bit much.

Cultural economists, (Levinson, 2000; Zelizer, 2002, 2005), have identified activities such as children's birthday parties, and their gift economies, as significant testament to children's economic activity. Unlike the gift relations between parent and off-spring (Clarke, 2007) the provisioning of birthday gifts does not involve overly complex mediations between child/adult. Rather choices of gifts (with the exception of 'best friends') relies on a heavily prescribed and general repertoire of material culture organised principally in accordance with gender/age appropriateness and cost allowing the easy circulation of goods and children in the production of social solidarity. Although, as asserted by more recent theoretical approaches to the research of childhood (James, 1993; Christensen; James, 2000), children are not merely objects of socialisation or 'adults-in-the-making', their agency here is internalised by the mothers and integrated as a vital part of the cultural and aesthetic repertoire of the desired birthday party.

Anne, the mother of four children ranging from seven to eleven years sees herself as 'an old-hand' at the birthday party gift buying. Although her 
children are now old enough to assert their opinions and choices regarding appropriate presents Anne still uses a pragmatic 'bulk-buy' approach to children's gift purchase. During the sales she identifies the kind of coveted children's items that are still fashionable enough to be sort after but destined to be replaced by a newer fad or edition, thereby reduced in price but not fully redundant in meaning. In the course of this ethnography Power Rangers plastic action figures were popular, for example, and Anne, on one particular shopping trip, found several items at special sale prices in the local department stores. She took the opportunity to buy them up in the hope that they would suffice for a number of parties the children would be attending later that year. By choosing such fashionable and child-centred objects Anne takes a risk that they be rendered completely undesirable by the time they are used as gifts thus placing her children in the embarrassing position of offering potentially 'out of date' presents. On the other hand she may manage to maximise contemporary appeal and price, thereby out-doing what she described as the 'rip-off kids merchandisers' into the bargain.

The type and extent of thought that went into gifts also revolved around the closeness a mother felt to understanding the gift repertoire of her 'group'; 'I just bought a jigsaw and it took all of one minute to chose - not because I didn't care but because it was just right. It's the kind of thing we buy for each other's kids'.

More anonymous or general types of presents (bubble bath, stickers, etc.) were often abandoned in favour of 'thoughtful' versions when mothers felt they knew the mother of the 'birthday' child more intimately. Celia, for example, used a two-tier price range directly correlating to the relationship she had with the mother of the child in question;

If I don't know the mother its less and if I know the mother and I'm good friends with her then it's more, so normally I tend to put my price range at $£ 5$, that is for or even less now that they can read I get them books, it's less than that sometimes it’s about $£ 3$ something like that depending...

Books and jigsaws are often given to the children of mothers less integrated into a group, as they are considered thoughtfully appropriate and imminently practical as they can be easily exchanged at local shops if duplicated. As well as creating a rationale behind the selection of gifts, the price limit and gift typing helped prevent further escalation of a performative party culture that, as 
previously mentioned, many informants viewed as potentially punitive. In some cases, mothers identified birthdays as times when children were most likely to make direct comparisons between themselves and individuals in their peer groups with the potential for revealing inequalities of wealth and creating ruptures with the group.

In her study of social solidarity and the gift economy, Komter (2005) observes how contemporary society has moved from an "organic" Durkheimian model of solidarity, to one built upon non-committal, segmented solidarities; 'cities, villages, quarters, and neighbourhoods have become hybrid and fragmented. Families can do without a neighbourhood if they like, and neighbourhoods do not need families.' (Komter, 2005, p. 211). No longer tied to mutual dependency and necessity, solidarities are formed as autonomous entities that, argues Komter, may increasingly come to rely upon the model of the gift economy to generate any form of mutually moral obligation. As women have been, and remain, the principle agents of 'gift work' (Cheal; 1988; Schrift, 1997; Strathern, 1988; Weiner, 1976, 1996) the perpetuation of such solidarities is 'clearly gendered' (Komter, 2005, p. 192).

Just as the fragmented solidarities generated through the networks of children's parties, mothers, infants and goods generate inclusion they also generate forms of exclusion. Although ambivalence towards holding children's parties is not necessarily experienced in direct relation to the financial security or affluence of a given household, for certain mothers the obligations of children's parties present an overt form of social tyranny. Jill a young, single mother with two children (the eldest four years old) living in Sparrow Court council estate, on welfare support can barely cover the costs of her monthly bills yet she understands her ability to attend the birthday parties of her children's classmates as a basic requisite of sociality as a mother;

I've been to nearly six so far [this year], but it's dreadful because their birthday is coming and I haven't got the money to buy them anything to have a party or anything. Carrie [daughter] has been to quite a few [classmates' parties] and one of David's [son] friends had to go to McDonalds and it's really expensive especially when there's about twelve or fourteen children and I can't even afford to get David a birthday card, let alone a party or anything. I feel quite embarrassed when they have to keep going to parties and I haven't really got a present but I sort of manage to get something like a colouring book from over the road [the corner shop] to show I appreciate going. 
Another mother, Irene, also living in Sparrow Court, with a younger son, categorically declares that she can no longer afford 'kids parties';

[There is] one that day, one the next day, so I've decided not to have birthday parties any more since they're too expensive by the time you've done party bags, drinks, games, food and all that. So none this year, but what can you do?

For Lola, a South American mother of two children recently moved to Jay Road, the choosing of birthday gifts for English children's parties is a fraught task in which she tries to reduce risk to a minimum. Lola is relatively unfamiliar with the local shopping area and depends on mail order catalogues almost exclusively for her non-food household provisioning. Although her two daughters are well versed in the gift and party etiquette of Chilean culture English birthday parties are a new form of sociality that have arisen through the girls recently formed friendships at the local school. Lola has little idea of how English children's parties operate and discovered, for example, through two embarrassing mistakes, that an invitation is confined to the named child and does not extend to a sibling. In contrast at Chilean parties it would be unthinkable to invite one sibling and not another and equally strange for the fathers not to attend; 'if it's a Chilean party all the family go and all the men - the family, all the whole family'.

Unlike many other children, Anita and Sofia play a significant role in choosing the gifts they take to their separate birthday parties as Lola relies almost exclusively on their experience and judgement. Together the mother and daughters read the Argos and Index store catalogues and the girls' select the presents, then, Lola visits the shop to buy them. The most recent gift, for example, was a pink snow-storm globe and a sewing craft kit bought for Anita's closet school friend. Unlike other mothers on the street Lola, despite her low income, buys the gifts on an individual and full-price basis and with only the guidance of her children, rather than the interactions of other mothers, to help her.

\section{Conclusion}

Whereas Bell and Ribbens's study of mothers' social networks considered how places and spaces of mothering 'allow' women to meet 'women of like mind, like children and the same social class' (Bell; Ribbens, 1994, p. 248), ethnographic detail reveals how women, in their exchanges of relations and material culture, do not merely reflect pre-existing modes of mothering and 
class disposition but rather generate and contest it. In the culture of the children's birthday parties mothers circulate their offspring, gifts and creativity in the generation of a sociality which exists in a constant tension between normative, competitive and expressive relations. Although children's parties exist across a spectrum of class and ethnic groups, this article reveals the processes by which certain types of mothering (in this case what evolves as a type of middle class mothering) might exist at the expense of the prominence of others. Mothers such as Jill, the single woman on the housing estate and Lola the South American mother, are not merely precluded from the children's 'party circuit' through lack of economic resources. They are excluded by the social and cultural domination of other solidarities of mothering at large in the locality; solidarities formed through endless rounds of children's parties and its ensuing gift economy. This domination may have real consequences, in for example, aiding access to certain types of schools though facilitation of local knowledge or other related resources.

While birthday parties might be understood as a crude series of escalating potlatches (in terms of the colloquial concept of competitive gifting that followed the popularisation of the term after Mauss), in actual fact the parties are far removed from this sense of direct competitive giving. Rather, they involve subtle and skilful positioning through a series of normative stages, each of which has its associated strategies and potentials. While there is at once a desire to use goods and gifts to express relationships and their depth (honouring a particular mother or child, for example with a more 'individually' chosen gift) the notion of the 'going rate' for the price of a children's party gift is crucial to the maintenance of 'sameness'. The expansion of the previously kin and home-based activity of the children's birthday party as a form of 'potlatch' (in which increasingly imaginative, commercialised or subtle variations of a theme are used to demonstrate the mother/child's worthiness and prestige) is testament to a contemporary British culture increasingly premised on the 'child' as a social object.

Despite the discourse regarding the unwanted intervention of the market into the 'authentic' relations of everyday domesticity, commercial services and goods are used by women to alleviate the pressures of potlatch party culture, and the potential for overly oppressive, idealised versions of competitive mothering. For venues such as Monkey Business soft-play venue, McDonalds fast food chain and Party Pieces catalogue, offer a less risky, neutralised default to the individually organised event. While American home-making guru Martha Stewart (or Camilla Knowles) type renditions of creative, expressive mothering 
might be popularly aspired to, in this ethnographic context they are regarded with the highest suspicion as they pose the greatest threat to a culture of negotiated 'sameness'. The woman most likely to garner admiration is the mother who 'gets away' with pulling off the most affective party with the minimal effort and expense, all within the bounds of the accepted aesthetic of the group.

The means by which women generate and perpetuate sociality in urban societies has been a crucial area of feminist scholarship, as has been the pressures of externally prescribed abstractions such as 'respectability' and normativity (Gullestad, 1986, 1992; Oliker, 1989; Skeggs, 1995, 1997). But few studies tie this sociality to broader issues of a 'feminist economics' (Still, 1997; Zelizer, 2002,2005 ) and the ways in which the commercialisation of mothering may enable, as much as exploit, women's contribution to the making of the 'social texture' of society (Komter, 2005).

Much literature deservedly deals with the social isolation of women as mothers, but, as is made evident by the ethnographic descriptions above, 'mothering' in fact operates as a key form of sociality. Contrary to Allan's depiction of British social relations (Allan, 1996, p. 103), which describes men as having a privileged access to the friendship ties and support networks of the public sphere while women remain isolated within the domestic sphere, in this ethnographic study men remain almost entirely absent from the social networks that define the prominent sociality of the locality. Their absence from the minutely detailed exchanges women make with, and around, other mothers and children in the course of social rituals such as children's birthday parties, impacts significantly on their role as potential care-givers (Radin, 1988) by excluding them from sensitively balanced culture of sameness their partners have sought to cultivate.

This carefully negotiated culture of sameness seen in the contemporary cult of children's birthday parties potentially allows women the opportunity for alternative modes of locally contested renditions of being a mother. But, as Komter (2005) argues there are also negative consequences emerging from a kind of solidarity that insures 'some people are excluded from the community whereas others are included, although sometimes at the cost of their own autonomy'. In this respect, a feminist discourse that once described the contradictions of women's consistent willingness to engage in 'invisible' labour has increasingly turned instead to the minutiae of the material culture and consumption of mothering and childhood as a means of analysis (Gutman; Connick-Smith, 2007; Layne, 1999; Taylor; Layne; Wozniak, 2004; Zelizer, 2002) 


\section{References}

ALLAN, Graham. Kinship and friendship in modern Britain. Oxford: Oxford University Press, 1996.

ANDERSON, Michael; BECHHOFER, Frank; GERSHUNY, Jonathan (Ed.). The social and political economy of the household. Oxford: Oxford University Press, 1994.

BELL, Linda; RIBBENS, Jane. Isolated housewives and complex maternal worlds - the significance of social contacts between women with young children in industrial societies. Sociological Review, v. 42, n. 2, p. 227-262, 1994.

CHEAL, David. The gift economy. London: Routledge, 1988.

CHRISTENSEN, Pia; JAMES, Allison (Ed.). Research with children: perspectives and practices. London: Falmer Press, 2000.

CLARKE, Alison J. Mother Swapping: The trafficking of nearly new children's wear. In: JACKSON, Peter et al. (Ed.). Commercial cultures: economies, practices, spaces. Oxford: Berg, 2000. p. 85-101.

CLARKE, Alison Jane. Maternity and materiality: becoming a mother in consumer culture. In: TAYLOR, Janelle; LAYNE, Linda; WOZNIAK, Danielle F. (Ed.). Consuming motherhood. New Brunswick: Rutgers University Press, 2004. p. 55-72.

CLARKE, Alison J. Coming of Age in suburbia: gifting the consumer child. In: GUTMAN, Marta; CONNICK-SMITH, Ning (Ed.). Designing modern childhoods: history, space, and the material culture of children. New Brunswick: Rutgers University Press, 2007 (forthcoming).

DAVIS, John. Exchange. Buckingham: Open University Press; Minneapolis: University of Minnesota Press, 1992.

DEVAULT, Marjorie. Feeding the family: the social organization of caring as gendered work. Chicago: Chicago University Press, 1991.

EVERINGHAM, Christine. Motherhood and modernity an investigation into the rational dimension of mothering. Buckingham: Open University Press, 1994.

FERBER, Marianne.; NELSON, Julie (Ed.). Beyond economic man feminist theory and economic. Chicago: University of Chicago Press, 1993. 
GULLESTAD, Marianne. Kitchen table society: a case study of family life and friendships of young working-class mothers in urban Norway. Oslo: Universitetsforlaget, 1986.

GULLESTAD, Marianne. The art of social relations: essays on culture, social action and everyday life in modern Norway. Oslo: Scandinavian University Press, 1992.

GUTMAN, Marta; CONNICK-SMITH, Ning (Ed.). Designing modern childhoods: history, space, and the material culture of children. New Brunswick: Rutgers University Press, 2007 (forthcoming).

HANDELMAN, Lea Shamgar; HANDELMAN, Don. Celebrations of bureaucracy: birthday parties in Israeli kindergartens. Ethnology, v. 30, p. 293312, October 1991.

JAMES, Allison. Childhood identities, self and social relationships: on the experience of the child. Edinburgh: Edinburgh University Press, 1993.

KOMTER, A. E. Social solidarity and the gift. Cambridge: Cambridge University Press, 2005.

LAREAU, Annette. Social class and the everyday lives of children. Childhood, v. 7, n. 2, p. 155-171, 2000.

LAYNE, Linda. Transformative mothering: on giving and getting in consumer culture. New York: New York University Press, 1999.

LEVISON, Diane. Children as economic agents. Feminist Economics, v. 6, p. 125-134, 2000.

MAUSS, Marcel. The gift forms and functions of exchange in archaic societies. London: Cohen and West, 1954.

McCANNELL, Kathryn. Social networks and the transition to motherhood. In: MILARDO, Richard (Ed.). Families and social networks. Newbury Park: Sage, 1988. p. 83-106.

McKENDRICK, John. H.; BRADFORD, Michael.G., FIEDLER, Anna. V. Time for a party! making sense of the commercialisation of leisure space for children. In: HOLLOWAY, Sarah L.; VALENTINE, Gill (Ed.). Children's geographies: playing, living, learning. London: Routledge, 2000. p. 100-119. 
MILLER, Daniel. John Lewis and the Cheapjack: a study of class and identity. In: MILLER, Daniel et al. (Ed.). Shopping, place and identity. London: Routledge, 1998. p. 139-159.

MILLER, Daniel. How infants grow mothers in North London. In: TAYLOR, Janelle; LAYNE, Linda; WOZNIAK, Danielle F. (Ed.). Consuming motherhood. New Brunswick: Rutgers University Press, 2004. p. 55-72.

MILLER, Daniel et al. (Ed.). Shopping, place and identity. London: Routledge, 1998.

OTNES, Cele.; NELSON, Michele.; MCGRATH, Mary Ann. The children's birthday party: a study of mothers as socialization agents. Advances in Consumer Research, v. 22, p. 622-627, 1995.

OLIKER, Stacey. J. Best friends and marriage: exchange among women. Berkeley: University of California Press, 1989.

PAHL, Ray. Divisions of Labour. Oxford: Basil Black, 1984.

PARKER, Rosika. Torn in two: the experience of maternal ambivalence. London: Virago Press, 2005.

RADIN, Norma. Primary care-giving fathers of long duration. In: BRONSTEIN, Phyllis.; COWAN, Carolyn. (Ed.). Fatherhood today: men's changing role in the family. New York: John Wiley, 1988. p. 127-143.

REDCLIFT, Nanneke; MINGIONE, Emzo. Beyond employment: household, gender and subsistence. Oxford: Blackwell, 1985.

SCHRIFT, Alan. The logic of the gift: toward an ethic of generosity. Routledge, 1997.

SEGALEN, Martine. Historical Anthropology of the family. Cambridge: Cambridge University Press, 1986.

SHARMA, Ursula. Women's work, class and the urban household: a study of Shimla, North India. London: Tavistock, 1986.

SIROTA, Régine. Les copains d'abord. Les anniversaires de l'enfance, donner and reçevoir. Ethnologie Française, n. 4, p. 457-472, 1998.

SKEGGS, Beverley. Theorising, ethics and representation in feminist ethnography. In: SKEGGS, Beverley. Feminist cultural theory, process and production. Manchester: Manchester University Press, 1995. p. 190-207. 
SKEGGS, Beverley. Formations of class and gender: becoming respectable. London: Sage, 1997.

STACEY, Jacqueline. Are feminists afraid to leave home? The challenge of conservative pro-family feminism. In: MITCHELL, Juliet.; OAKLEY, Anne (Ed.). What is Feminism? Oxford: Basil Blackwell, 1986. p. 208 -237.

STILL, Judith. Feminine economies: thinking against the market in the Enlightenment and the late $20^{\text {th }}$ century. Manchester: Manchester University Press, 1997.

STRATHERN, Marylin. The Gender of the Gift. Berkeley: University of California Press, 1988.

TAYLOR, Janelle; LAYNE, Linda; WOZNIAK, Danielle F. (Ed.). Consuming motherhood. New Brunswick: Rutgers University Press, 2004.

TIVERS, Jacqueline. Women attached: the daily lives of women with young children. London: Croom Helm, 1985.

WALLMAN, Sandra. Eight London households. London: Tavistock, 1984.

WEINER, Annette. Women of value, men of renown: new perspectives in Trobriand exchange. Austin: University of Texas Press, 1976.

WEINER, Annette. Inalienable possessions: the paradox of keeping while giving. California: UCLA Press, 1996.

WERBNER, Pnina. The Migration Process: Capital, Gifts and Offerings among British Pakistanis. Oxford: Berg, 1990.

ZELIZER, Viviana. Kids and commerce. Childhood, v. 9, n. 4, p. 375-396, 2002.

ZELIZER, Viviana. The Purchase of Intimacy Princeton, N.J., Chichester: Princeton University Press, 2005 